\title{
Analisis Volatilitas Harga Saham Sekor Minyak dan Gas di Indonesia pada Masa Pandemi Covid-19 dengan Metode ARIMA-GARCH
}

\author{
Nanda Septiana ${ }^{(1)}$, Primadina Hasanah ${ }^{(2)}$, Annisa Rahmita Soemarsono ${ }^{(3)}$ \\ Institut Teknologi Kalimantan \\ Jl. Soekarno-Hatta Km. 15, Karang Joang Telp. (0542) 8530800 Balikpapan 76127 \\ e-mail: nanda18septiana@gmail.com, primadina@lecturer.itk.ac.id, dan \\ annisarahmitas@lecturer.itk.ac.id
}

\begin{abstract}
ABSTRAK
Pandemi Covid-19 memberi dampak yang signifikan terhadap berbagai sektor industri di Indonesia salah satunya saham sektor pertambangan Minyak Mentah dan Gas Bumi (MIGAS). Hal ini ditunjukkan pada penurunan harga minyak yang turun di bawah \$40 USD dan aktivitas eksplorasi di Indonesia menurun lebih dari 40\% dibanding sebelum pandemi Covid-19. Selama pandemi, harga saham sektor pertambangan MIGAS mengalami volatilitas yang cukup tinggi sehingga cukup meresahkan sektor investasi di Indonesia. Volatilitas merupakan naik turunnya harga saham atau sekuritas dalam kurun waktu tertentu. Oleh karena itu, diperlukan suatu prediksi volatilitas harga saham sektor pertambangan MIGAS agar mampu memberikan informasi terhadap investor untuk melakukan manajemen portofolio. Pada penelitian ini, dianalisis volatilitas harga saham empat perusahaan pertambangan MIGAS, yaitu PT. Apexindo Pratma Duta (APEX), PT. Elnusa (ELSA), PT. Medco Energi Internasional (MEDC), dan PT. Radiant Utama Interinsco (RUIS) pada tanggal 01 Maret 2020 - 28 Februari 2021 dengan metode ARIMA-GARCH. ARIMA-GARCH merupakan metode analisis data dengan memodelkan suatu data stasioner dengan model Autoregresive (AR) dan Moving Average (MA) yang memiliki gejala heteroskedastisitas pada model ARIMA. Pada proses analisis, digunakan RStudio dengan pembentukan model ARIMA dilakukan terlebih dahulu kemudian dilanjutkan pembentukan model ARIMA-GARCH jika model ARIMA terdapat gejala heteroskedastisitas. Hasil dari penelitian ini, pada saham APEX, ELSA, dan RUIS terdapat gejala heteroskedastisitas pada model ARIMA dan didapatkan model ARIMA(0,1,1)GARCH(1,1) untuk perusahaan APEX, ELSA dan RUIS serta model ARIMA $(4,1,4)$ untuk perusahaan MEDC. Berdasarkan hasil analisis, diperoleh bahwa terdapat asumsi autokorelasi, normalitas, dan heteroskedastisitas yang belum terpenuhi pada uji diagnostik. Niilai MAPE untuk APEX, ELSA, MEDC, dan RUIS, yaitu 67.32667\%, 42.49374\%, 5.269889\%, dan 4.113383\%. Dari hasil akurasi peramalan yang didapatkan, terdapat nilai MAPE di atas 10\%, yaitu pada model APEX dan ELSA sehingga model tersebut belum dapat dikatakan baik untuk peramalan.
\end{abstract}

Kata kunci : ARIMA, GARCH, Volatilitas Harga Saham

\begin{abstract}
The Covid-19 pandemic has significant impacst on various industrial sectors in Indonesia, one of them is the Crude Oil and Natural Gas (Oil and Gas) stocks. The impact was showed by the conditional of oil prices that have fallen below \$40 USD and exploration activities in Indonesia has decreased by more than $40 \%$ compared by condition before the pandemic. During the pandemic the stock price of Oil and Gas mining sector have experienced high volatility which is confusing the investement sectors in Indonesia. Volatility is the fluctuation of stocks over a certain period of time. Therefore, a prediction of stock price volatility in oil and gas mining sectors is needed in order to provide information for the investors to manage their portofolio. In this study, the stock prices volatility of four oil and gas companies was analyzed, namely PT. Apexindo Pratma Duta (APEX), PT. Elnusa (ELSA), PT. Medco Energi Internasional (MEDC), and PT. Radiant Utama Interinsco (RUIS) on 01 March 2020 - 28 February 2021 using the ARIMA-GARCH method. ARIMA-GARCH is a data analysis method by modeling stationary data with Autoregressive (AR) and Moving Average (MA) models which have heteroscedasticity in the ARIMA model. In the analysis process, Rstudio is used with the formation of the ARIMA was conducted first then it is
\end{abstract}


continude by the ARIMA-GARCH model if the ARIMA model has the heteroscedasticity. The results of this study, have obtained the ARIMA(0,1,1)GARCH(1,1) model for APEX, ELSA and RUIS and the ARIMA $(4,1,4)$ model for MEDC. Based on the results, it is found that there were autocorrelation, normality, and heteroscedasticity the residual that have not been met in the diagnostic test. MAPE values for APEX, ELSA, MEDC, and RUIS were 67.32667\%, 42.49374\%, 5.269889\%, and 4.113383\%. From the results of forecasting accuracy obtained that were MAPE value above 10\%, namely in APEX and ELSA models so that the model is not suggested for the forecasting.

Keywords : ARIMA, GARCH, Stock Price Volatility.

\section{PENDAHULUAN}

Banyak sektor yang terpukul pada saat Covid-19 Rp. 500 per lembar, dan PT. Radiant Utama mewabah di Indonesia. Sektor pertambangan Interinsco (RUIS) dari Rp. 200 per lembar menjadi khususnya pertambangan Minyak Mentah dan Gas Rp.100 per lembar. Para investor menyukai saham Bumi (MIGAS) dilihat dari penurunan harga yang memiliki volatilitas tinggi, karena dapat minyak yang turun di bawah \$40 USD dan memungkinkan mereka memperoleh keuntungan aktivitas eksplorasi di Indonesia menurun lebih dari yang besar dalam waktu yang singkat tetapi hal ini 40\% dibanding sebelum pandemi Covid-19. juga dapat mengakibatkan kerugian yang cukup Menurut Menteri Keuangan Republik Indonesia, besar. Cara untuk menghindari hal tersebut maka sektor manufaktur dan pertambangan minyak dibutuhkan model yang tepat untuk memprediksi mentah dan gas bumi terpukul saat Covid-19, di volatilitas harga saham.

mana permintaan menurun sangat signifikan. Hal ini

berimbas pada penurunan saham pada pertambangan minyak mentah dan gas bumi

(Widyastuti dan Hanan, 2020).

Menurut Organisasi untuk Kerja sama dan pada tahun 2017, yaitu penerapan model ARIMAPembangunan Ekonomi atau Organization for GARCH untuk memprediksi harga saham Bank BRI. Economic Co-operation and Development ARIMA-GARCH sendiri merupakan metode (OECD), Covid-19 berpotensi menimbulkan krisis analisis data dengan memodelkan suatu data ekonomi dunia. Terbukti dengan adanya wabah stasioner dengan model Autoregresive (AR) dan virus ini telah memukul berbagai bidang ekonomi Moving Average (MA) yang memiliki gejala yang membawa dampak yang signifikan terhadap heteroskedastisitas pada model ARIMA. perdagangan di bursa. Penurunan dan peningkatan Digunakan metode ARIMA-GARCH karena pada permintaan jasa berbanding lurus dengan rendah hal volatilitas harga saham tidak terlepas dari tingginya harga saham yang nantinya akan gejala heteroskedastisitas, dimana data tersebut berimbas pada penurunan atau peningkatan harga memiliki varian yang tidak konstan. Maka dari itu saham (Darmayanti dkk., 2020). Hal ini yang digunakan metode ARIMA-GARCH untuk disebut juga volatilitas harga saham. Volatilitas mengatasi gejala heteroskedastisitas. Pada harga saham menggambarkan fluktuasi atau naik penelitiannya didapatkan kesimpulan bahwa model turun pada harga saham sehingga akan ARIMA-GARCH untuk prediksi harga saham BRI, menunjukkan risiko pada investor (Raneo dkk., yaitu ARIMA(2,1,1)GARCH(2,2) dengan nilai 2018).

Volatilitas tinggi menunjukkan bahwa harga saham

naik dan turun dengan range yang besar. Pada penelitian ini, dikaji mengenai analisis Sedangkan volatilitas rendah menunjukkan bahwa volatilitas harga saham sektor pertambangan harga saham cenderung konstan atau jarang minyak mentah dan gas bumi di Indonesia pada berubah. Hal ini ditunjukan dengan turunnya harga masa Covid-19. Studi kasus yang diambil, yaitu saham perusahaan sektor pertambangan MIGAS PT. Apexindo Pratama Duta Tbk (APEX), PT. pada awal maret yang merupakan awal mula ElnusaTbk (ELSA), PT. Medco Energi Covid-19 menyebar di Indonesia yang mengalami Internasional Tbk (MEDC), dan PT. Radiant volatilitas yang cukup tinggi, yaitu pada Utama Interinsco Tbk (RUIS). Pada langkah PT.Apexindo Pratama Duta. Tbk (APEX) dan PT. analisis, terdapat unsur heteroskedastisitas pada Elnusa. Tbk (ELSA) dari harga saham mencapai pembentukan model ARIMA sehingga Rp.300 per lembar kemudian turun mejadi Rp.100 digunakan metode ARIMA-GARCH. per lembar, PT. Medco Energi Internasional Berdasarkan hasil

Nanda Septiana ${ }^{1}$, Primadina Hasanah ${ }^{2}$, Annisa Rahmita Soemarsono ${ }^{3 /}$

J Statistika Vol. 14, No. 2, (2021) 
analisis, diperoleh ARIMA-GARCH terbaik untuk peramalan dengan nilai eror yang kecil. Maka dari itu, pada penelitian ini akan dianalisis tentang harga saham sektor pertambangan MIGAS, yaitu perusahaan APEX, ELSA, MEDC, dan RUIS pada masa Covid-19 dengan metode ARIMA-GARCH.

\section{METODE PENELITIAN}

Pada penelitian ini, akan dibentuk model ARIMAGARCH dimana model tersebut secara umum dinyatakan sebagai berikut:

A. Model ARIMA

$$
\begin{aligned}
& \phi_{p}(B)(1-B)^{d} Y_{t}=\theta_{q}(B) e_{t} \\
& \text { dengan } \\
& \phi_{p}(B)=\left(1-\phi_{1} B-\phi_{2} B^{2}-\cdots-\phi_{p} B^{p}\right), \\
& \theta_{q}(B)=\left(1+\theta_{1} B+\theta_{2} B^{2}+\cdots+\theta_{q} B^{q}\right)
\end{aligned}
$$

di mana $p$ merupakan orde AR, $q$ merupakan orde MA, $d$ merupakan orde differencing, $\phi_{p}$ merupakan parameter $\mathrm{AR}, \theta_{q}$ parameter MA, $e_{t}$ merupakan nilai residual, dan $B$ merupakan operator backshift. Sebagai contoh dalam pembentukan persamaan model ARIMA, yaitu pada model ARIMA $(1,1,1)$ sebagai berikut:

$\left(1-\phi_{1} B\right)(1-B) Y_{t}=\left(1+\theta_{1} B\right) e_{t}$

$\left(1-B-\phi_{1} B+\phi_{1} B^{2}\right) Y_{t}=e_{t}+\theta_{1} B e_{t}$

$Y_{t}-B Y_{t}-\phi_{1} B Y_{t}+\phi_{1} B^{2} Y_{t}=e_{t}+\theta_{1} B e_{t}$

$Y_{t}=B Y_{t}+\phi_{1} B Y_{t}-\phi_{1} B^{2} Y_{t}+\theta_{1} B e_{t}+e_{t}$

$Y_{t}=Y_{t-1}+\phi_{1} Y_{t-1}-\phi_{1} Y_{t-2}+\theta_{1} B e_{t}+e_{t}$

Berdasarkan Persamaan diatas, didapatkan persamaan matematis dari model $\operatorname{ARIMA}(1,1,1)$.

B. Model GARCH

$\sigma_{t}^{2}=\alpha_{0}+\alpha_{1} e^{2}{ }_{t-1}+\cdots+\alpha_{p} e^{2}{ }_{t-p}+$

$\beta_{1} \sigma_{t-1}^{2}+\cdots+\beta_{q} \sigma_{t-q}^{2}$

dengan $\sigma_{t}^{2}$ merupakan variabel varian residual pada waktu t, $\alpha_{0}$ merupakan konstanta, $\alpha_{p}$ koefisien ARCH pada orde ke- $p$, dan $e_{t-1}^{2}$ merupakan residual kuadrat pada waktu $t-p$, $\beta_{q}$ koefisien GARCH pada orde ke- $q$, dan $\sigma_{t-q}^{2}$ merupakan variabel varian residual pada waktu $t-q$.

Pada penelitian ini data yang digunakan dalam adalah data daily closed price atau harga saham penutupan harian dari 4 perusahaan sektor pertambangan MIGAS di Indonesia dan terdaftar di Bursa Efek Indonesia (BEI), yaitu yaitu PT. Apexindo Pratama Duta Tbk (APEX), PT. ElnusaTbk (ELSA), PT. Medco Energi Internasional Tbk (MEDC), dan PT. Radiant Utama Interinsco Tbk (RUIS). Data ini dapat diakses dari situs web www.finance.yahoo.com dimana data yang diambil yaitu pada periode pandemi Covid-19 di Indonesia mulai tanggal 1 Maret 2020 sampai dengan 28 Februari 2021.

Langkah analisis dimulai dengan plot time series dan menghitung statistik deskriptif harga saham masing-masing perusahaan, langkah berikutnya dilakukan uji stasioneritas, yaitu stasioner terhadap mean dengan uji Augmented Dickey-Fuller (ADF) dan stasioner terhadap varian dengan melihat nilai lambda dari plot Box-Cox di mana jika lambda tidak bernilai 1 maka akan dilakuakan transformasi Box-Cox. Data yang telah stasioner akan dilihat Correlogram ACF dan PACF yang digunakan untuk pendugaan orde ARIMA. Berdasarkan pendugaan orde ARIMA, dilakukan uji signifikansi parameter terhadap orde pendugaan dan orde yang telah overfitting. Model terbaik dipilih berdasarkan nilai Mean Absolut Percentage Error (MAPE) terkecil.

Pada model ARIMA terbaik diuji apakah terdapat gejala heteroskedastisitas dengan uji ARCH-LM. Jika terdapat gejala heteroskedastisitas maka akan dimodelkan dengan GARCH. Orde GARCH diperoleh dari Correlogram ACF dan PACF residual kuadrat dari model ARIMA. Selanjutnya dilakukan uji signifikansi dan uji diagnostik untuk model ARIMA-GARCH. Setelah didapatkan model terbaik maka dilakukan peramalan harga saham untuk 4 perusahaan dan dihitung akurasi peramalan dengan data aktual menggunakan MAPE.

\section{HASIL DAN PEMBAHASAN}

A. Statistika Deskriptif

Pada penelitian ini, dilakukan statistika deskriptif untuk melihat karakteristik dari data harga penutupan sahan(2. h\&)ian. Hasil statistika deskriptif pada masing masing 4 perusahaan dapat dilihat dari Tabel 1.

Tabel 1. Statistika deskriptif

\begin{tabular}{|c|c|c|c|c|}
\hline & APEX & ELSA & MEDC & RUIS \\
\hline$N$ & 239 & 239 & 239 & 239 \\
\hline Mean & 239 & 259.07 & 462.88 & 230.70 \\
\hline SD & 185.62 & 81.418 & 119.85 & 58.415 \\
\hline Median & 157 & 230 & 408 & 228 \\
\hline Min & 89 & 129 & 264.12 & 150 \\
\hline Max & 157 & 498 & 735 & 340 \\
\hline
\end{tabular}

Ukuran statistika deskriptif dari 4 perusahaan ditampilkan pada Tabel 1. yang meliputi jumlah data, rata-rata, standar deviasi, median, nilai minimum, dan nilai maksimum. Pada statistika deskriptif, digunakan harga penutupan saham 
harian dari tanggal 01 Maret 2020 sampai 28 Februari 2021. Pada statistika deskrptif, dapat dikatakan bahwa terjadi fluktuasi harga penutupan saham harian pada masing-masing 4 perusahaan. Untuk melihat lebih jelas, berikut plot time series harga penutupan saham untuk masing-masing 4 perusahaan.

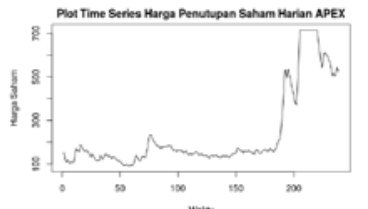

(a)

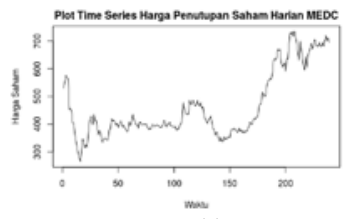

(c)

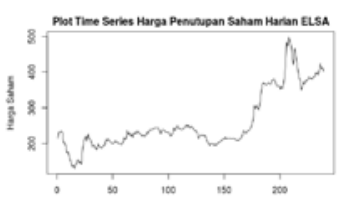

(b)

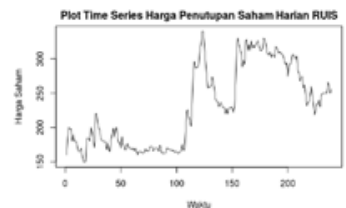

(d)
Gambar 1. Plot Time Series harga penutupan saham harian (a) APEX, (b) ELSA, (c) MEDC, (d) RUIS

Berdasarkan plot time series, dapat dilihat bahwa terdapat pola fluktuatif pada data harga penutupan saham harian 4 perusahaan. Pada Gambar 1, dapat dilihat juga terdapat pola trend pada harga saham ELSA, MEDC, dan, RUIS. Sedangkan untuk harga saham APEX cenderung konstan. Harga saham pada 4 perusahaan sektor pertambangan minyak mentah dan gas bumi ini mengalami volatilitas yang cenderung tinggi dan dapat menimbulkan resiko untuk investor yang akan berinvestasi maupun yang telah berinvestasi di salah satu 4 perusahaan, yaitu APEX, ELSA, MEDC, dan RUIS.

\section{B. Uji Stasioneritas}

Berdasarkan plot data, terlihat bahwa data belum stasioner, masih terlihat naik turunnya atau fluktuatif dari data harga penutupan saham 4 perusahaan. Oleh karena itu, data harus distasionerkan baik dalam rata-rata maupun varian karena dalam metode ARIMA-GARCH data yang dianalisis harus stasioner. Langkah awal dalam uji stasioner, yaitu uji satsioner terhadap rata-rata. Pada uji stasioner terhadap rata-rata data diuji dengan uji ADF dengan hipotesis $H_{0}$ data belum satasioner dan taraf signifikansi $\alpha=0.05$.

Tabel 2. Hasil uji ADF

\begin{tabular}{|c|c|c|}
\hline Data & $p$-value & Kesimpulan \\
\hline APEX & 0.6826 & Belum Stasioner \\
\hline
\end{tabular}

\begin{tabular}{|c|l|l|}
\hline ELSA & 0.4895 & Belum Stasioner \\
\hline MEDC & 0.3498 & Belum Stasioner \\
\hline RUIS & 0.5459 & Belum Stasioner \\
\hline
\end{tabular}

Berdasarkan uji hipotesis untuk uji ADF tersebut didapatkan kesimpulan bahwa data harga penutupan saham harian 4 perusahaan belum stasioner terhadap rata-rata, sehingga dilakukan differencing atau proses diferensi agar data stasioner terhadap rata-rata. Setelah dilakuakan differencing, maka dilakukan uji ADF kembali dari data yang sudah dilakukan differencing.

Tabel 3. Hasil uji ADF setelah diffrencing

\begin{tabular}{|c|c|c|}
\hline Data & $p$-value & Kesimpulan \\
\hline APEX & 0.01 & Stasioner \\
\hline ELSA & 0.01 & Stasioner \\
\hline MEDC & 0.01 & Stasioner \\
\hline RUIS & 0.01 & Stasioner \\
\hline
\end{tabular}

Dapat dilihat uji hipotesis dari uji ADF didapatkan kesimpulan bahwa data stasioner. Selanjutnya dilakukan uji stasioner terhadap varian dengan melihat nilai lambda plot Box-Cox.

Tabel 4. Nilai lambda pada plot Box-Cox

\begin{tabular}{|c|c|}
\hline Data & Nilai Lambda \\
\hline APEX & 0.552 \\
\hline ELSA & 0.694 \\
\hline MEDC & 1 \\
\hline RUIS & 0.559 \\
\hline
\end{tabular}

Dapat dilihat nilai lambda APEX, ELSA, dan RUIS tidak menunjukkan nilai 1 yang artinya belum stasioner terhadap varian, maka dari itu perlu adanya transformasi data di mana masingmasing data akan di transformasi karena nilai $\lambda \neq 0$ dan untuk MEDC tidak perlu ada transformasi data karena nilai lambda menunjukkan nilai 1. Transformasi Box-Cox sebagai berikut:

$Y_{\text {trans }}=\frac{Y^{\lambda}-1}{\lambda} \quad, \lambda \neq 0$

$Y_{\text {trans }}=\ln Y \quad, \lambda=0$

Dari persamaan (1) dan (2), untuk mengembalikan data transformasi ke data asli sebagai berikut

$Y=\left(\left(\lambda \times Y_{\text {trans }}\right)+1\right)^{1 / \lambda}, \lambda \neq 0$ 
$Y=e^{Y_{\text {trans }}}$

$$
, \lambda=0
$$

\section{Estimasi Model ARIMA}

Pada estimasi model $\operatorname{ARIMA}(p, d, q)$ dilakukan dengan metode maximum likelihood dengan orde $p, d$, dan $q$ dapat dilihat pada correlogram ACF dan PACF. Orde $p$ merupakan orde AR yang dapat dilihat pada correlogram PACF, orde $q$ merupakan orde MA dapat dilihat pada correlogram ACF, sedangkan orde $d$ merupakan proses diferensi yang dilakukan pada pengolahan data. Berikut correlogram ACF dan PACF masing-masing perusahaan:
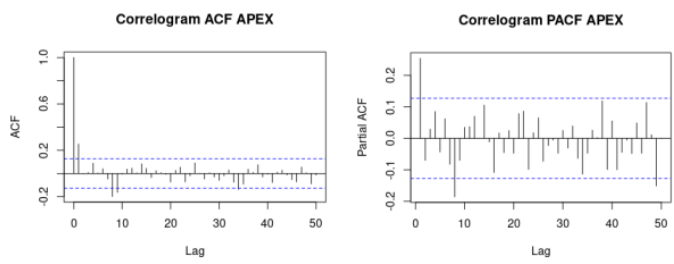

(a)
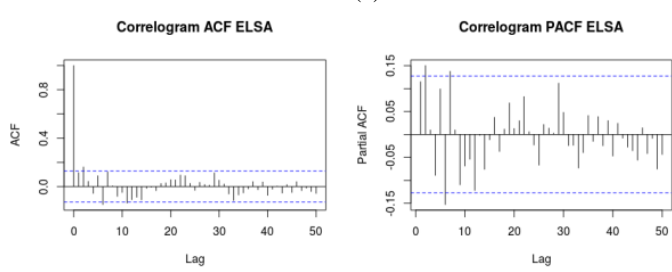

(b)
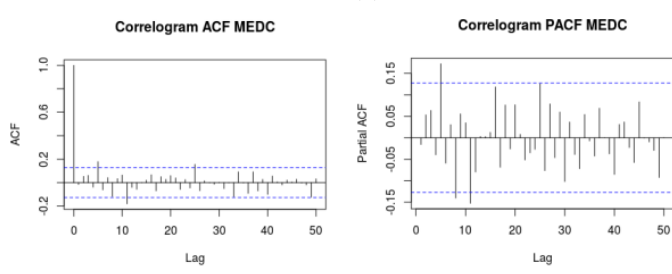

(c)
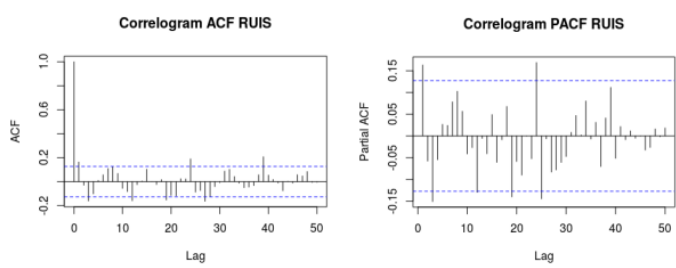

(d)

Gambar 2. Correlogram ACF dan PACF (a) APEX, (b) ELSA, (c) MEDC, (d) RUIS

Dalam pendugaan model dengan correlogram ACF dan PACF, masing-masing 4 perusahaan menunjukkan lag yang keluar batas atau cut off . Pada ACF APEX, terpotong pada lag 0 dan 1. Untuk PACF APEX terpotong pada lag 1. Sehingga pendugaan model ARIMA APEX, yaitu ARIMA $(1,1,0)$ dan $\operatorname{ARIMA}(1,1,1)$. Pada ACF ELSA, terpotong pada lag 0 dan 2. Untuk PACF
ELSA terpotong pada lag 2. Sehingga pendugaan model ARIMA ELSA, yaitu ARIMA $(2,1,0)$ dan $\operatorname{ARIMA}(2,1,2)$. Pada ACF MEDC, terpotong pada lag 0 dan 5. Untuk PACF MEDC terpotong pada lag 5. Sehingga pendugaan model ARIMA MEDC, yaitu $\operatorname{ARIMA}(5,1,0)$ dan $\operatorname{ARIMA}(5,1,5)$. Pada ACF RUIS, terpotong pada lag 0,1 , dan 3 . Untuk PACF RUIS terpotong pada lag 1 dan 3. Sehingga pendugaan model ARIMA RUIS, yaitu $\operatorname{ARIMA}(1,1,0), \operatorname{ARIMA}(1,1,1), \operatorname{ARIMA}(1,1,3)$, $\operatorname{ARIMA}(3,1,0), \quad \operatorname{ARIMA}(3,1,1), \quad$ dan $\operatorname{ARIMA}(3,1,3)$. Setelah didapatkan orde ARIMA dilakukan estimasi parameter untuk uji signifikan model pendugaan dan model overfitting dengan hipotesis $H_{0}$ model tidak signifikan. Hasil estimasi parameter dari model ARIMA APEX disajikan pada Tabel 5.

Tabel 5. Hasil estimasi parameter model ARIMA APEX

\begin{tabular}{|c|c|c|c|c|}
\hline Model & Parameter & Coefficient & $p$-value & Signifikan \\
\hline $\begin{array}{c}\text { ARIMA } \\
(1,1,0)\end{array}$ & $\operatorname{AR}(1)$ & 0.4325 & $1.058 \times 10^{-13}$ & Ya \\
\hline \multirow{2}{*}{$\begin{array}{c}\text { ARIMA } \\
(1,1,1)\end{array}$} & $\operatorname{AR}(1)$ & 0.36086 & 0.006607 & \multirow{2}{*}{ Tidak } \\
\hline & MA(1) & 0.08872 & 0.529078 & \\
\hline $\begin{array}{c}\text { ARIMA } \\
(0,1,1) \\
\end{array}$ & $\mathrm{MA}(1)$ & 0.3902 & $4.02 \times 10^{-14}$ & Ya \\
\hline \multirow{2}{*}{$\begin{array}{l}\text { ARIMA } \\
(0,1,2) \\
\end{array}$} & MA(1) & 0.4484 & $3.138 \times 10^{-12}$ & \multirow{2}{*}{ Ya } \\
\hline & MA(2) & 0.1508 & 0.01311 & \\
\hline \multirow{3}{*}{$\begin{array}{c}\text { ARIMA } \\
(2,1,1)\end{array}$} & $\mathrm{AR}(1)$ & 1.1940 & $8.869 \times 10^{-8}$ & \multirow{3}{*}{ Ya } \\
\hline & $\mathrm{AR}(2)$ & -0.3676 & 0.0002049 & \\
\hline & MA(1) & -0.7447 & 0.0008888 & \\
\hline
\end{tabular}

Berdasarkan Tabel 5, didapatkan bahwa terdapat dua model ARIMA APEX yang signifikan, yaitu ARIMA $(1,1,0)$, ARIMA $(0,1,1)$, $\operatorname{ARIMA}(0,1,2)$, dan $\operatorname{ARIMA}(2,1,1)$. Hasil estimasi parameter dari model ARIMA ELSA disajikan pada Tabel 6 .

Tabel 6. Hasil estimasi parameter model ARIMA ELSA

\begin{tabular}{|c|c|c|c|c|}
\hline Model & Parameter & Coefficient & p-value & Signifikan \\
\hline \multirow{2}{*}{$\begin{array}{c}\text { ARIMA } \\
(2,1,0)\end{array}$} & $\operatorname{AR}(1)$ & 0.090300 & 0.16075 & \multirow{2}{*}{ Tidak } \\
\hline & $\overline{\operatorname{AR}(2)}$ & 0.157438 & 0.01434 & \\
\hline \multirow{4}{*}{$\begin{array}{c}\text { ARIMA } \\
(2,1,2)\end{array}$} & $\overline{A R(1)}$ & 0.194984 & 0.6864 & \multirow{4}{*}{ Tidak } \\
\hline & $\operatorname{AR}(2)$ & -0.061237 & 0.8347 & \\
\hline & MA(1) & -0.105692 & 0.8233 & \\
\hline & $\mathrm{MA}(2)$ & 0.222783 & 0.3887 & \\
\hline $\begin{array}{c}\text { ARIMA } \\
(1,1,0)\end{array}$ & $\operatorname{AR}(1)$ & 0.107595 & 0.0971 & Tidak \\
\hline \multirow{2}{*}{$\begin{array}{c}\text { ARIMA } \\
(1,1,1) \\
\end{array}$} & $\mathrm{AR}(1)$ & 0.63339 & 0.0008306 & \multirow{2}{*}{ Ya } \\
\hline & MA(1) & -0.51001 & 0.0138721 & \\
\hline \multirow{3}{*}{$\begin{array}{c}\text { ARIMA } \\
(2,1,1)\end{array}$} & $\mathrm{AR}(1)$ & 0.150528 & 0.60067 & \multirow{3}{*}{ Tidak } \\
\hline & $\mathrm{AR}(2)$ & 0.151192 & 0.03672 & \\
\hline & MA(1) & -0.061706 & 0.82979 & \\
\hline \multirow{4}{*}{$\begin{array}{c}\text { ARIMA } \\
(3,1,1)\end{array}$} & $\mathrm{AR}(1)$ & -0.771282 & $2.862 \times 10^{-13}$ & \multirow{4}{*}{ Ya } \\
\hline & $\mathrm{AR}(2)$ & 0.225349 & 0.0049454 & \\
\hline & $\operatorname{AR}(3)$ & 0.222413 & 0.0005866 & \\
\hline & MA(1) & 0.873831 & $2.2 \times 10^{-16}$ & \\
\hline \multirow{3}{*}{$\begin{array}{c}\text { ARIMA } \\
(3,1,2)\end{array}$} & $\mathrm{AR}(1)$ & -1.143860 & $2.2 \times 10^{-16}$ & \multirow{3}{*}{ Ya } \\
\hline & $\mathrm{AR}(2)$ & -0.566170 & $3.421 \times 10^{-7}$ & \\
\hline & $\operatorname{AR}(3)$ & 0.231352 & 0.000687 & \\
\hline
\end{tabular}




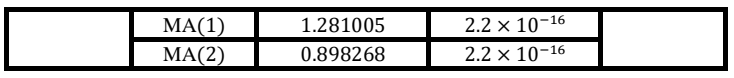

Berdasarkan Tabel 6, didapatkan model yang signifikan, yaitu ARIMA $(1,1,1), \operatorname{ARIMA}(3,1,2)$, dan ARIMA $(3,1,1)$. Hasil estimasi parameter dari model ARIMA MEDC disajikan pada Tabel 7.

Tabel 7. Hasil estimasi parameter model ARIMA MEDC

\begin{tabular}{|c|c|c|c|c|}
\hline Model & Parameter & Coefficient & p-value & Signifikan \\
\hline \multirow{5}{*}{$\begin{array}{c}\text { ARIMA } \\
(5,1,0)\end{array}$} & $\mathrm{AR}(1)$ & -0.00026448 & 0.996687 & \multirow{5}{*}{ Tidak } \\
\hline & $\mathrm{AR}(2)$ & 0.03843147 & 0.547416 & \\
\hline & $\mathrm{AR}(3)$ & 0.05247552 & 0.409665 & \\
\hline & $\operatorname{AR}(4)$ & -0.06355707 & 0.318549 & \\
\hline & $\mathrm{AR}(5)$ & 0.19845796 & 0.003566 & \\
\hline \multirow{10}{*}{$\begin{array}{c}\text { ARIMA } \\
(5,1,5)\end{array}$} & $\operatorname{AR}(1)$ & -0.603619 & 0.996687 & \multirow{10}{*}{ Tidak } \\
\hline & AR(2) & -0.108925 & 0.547416 & \\
\hline & $\mathrm{AR}(3)$ & -0.558597 & 0.409665 & \\
\hline & $\mathrm{AR}(4)$ & 0.010860 & 0.318549 & \\
\hline & AR(5) & 0.701730 & 0.003566 & \\
\hline & $\mathrm{MA}(1)$ & 0.737452 & 0.996687 & \\
\hline & $\mathrm{MA}(2)$ & 0.144162 & 0.547416 & \\
\hline & MA(3) & 0.660708 & 0.409665 & \\
\hline & MA(4) & 0.047215 & 0.318549 & \\
\hline & MA(5) & -0.671001 & 0.003566 & \\
\hline $\begin{array}{c}\text { ARIMA } \\
(1,1,0)\end{array}$ & $\operatorname{AR}(1)$ & -0.0093016 & 0.8861 & Tidak \\
\hline \multirow{2}{*}{$\begin{array}{c}\text { ARIMA } \\
(1,1,1)\end{array}$} & $\mathrm{AR}(1)$ & -0.025690 & 0.02619 & \multirow{2}{*}{ Ya } \\
\hline & MA(1) & -0.981238 & 0.03838 & \\
\hline $\begin{array}{l}\text { ARIMA } \\
(0,1,1)\end{array}$ & $\operatorname{MA}(1)$ & -0.0084149 & 0.8916 & Tidak \\
\hline \multirow{4}{*}{$\begin{array}{c}\text { ARIMA } \\
(2,1,2)\end{array}$} & $\operatorname{AR}(1)$ & 1.163614 & $2.2 \times 10^{-16}$ & \multirow{4}{*}{ Ya } \\
\hline & $\mathrm{AR}(2)$ & -0.970528 & $2.2 \times 10^{-16}$ & \\
\hline & $\mathrm{MA}(1)$ & $-1,173293$ & $2.2 \times 10^{-16}$ & \\
\hline & $\mathrm{MA}(2)$ & 0.999935 & $2.2 \times 10^{-16}$ & \\
\hline \multirow{8}{*}{$\begin{array}{c}\text { ARIMA } \\
(4,1,4)\end{array}$} & $\mathrm{AR}(1)$ & -0.639064 & $2.2 \times 10^{-16}$ & \multirow{8}{*}{ Ya } \\
\hline & $\operatorname{AR}(2)$ & 0.188087 & 0.002193 & \\
\hline & $\mathrm{AR}(3)$ & -0.641934 & $2.2 \times 10^{-16}$ & \\
\hline & $\operatorname{AR}(4)$ & -0.936179 & $2.2 \times 10^{-16}$ & \\
\hline & MA(1) & 0.711261 & $2.2 \times 10^{-16}$ & \\
\hline & $\mathrm{MA}(2)$ & -0.221940 & $3.717 \times 10^{-8}$ & \\
\hline & MA(3) & 0.712097 & $2.2 \times 10^{-16}$ & \\
\hline & MA(4) & 0.999032 & $2.2 \times 10^{-16}$ & \\
\hline
\end{tabular}

Berdasarkan Tabel 7, didapatkan model yang signifikan, yaitu ARIMA(1,1,1), $\operatorname{ARIMA}(2,1,2)$, dan ARIMA $(4,1,4)$. Hasil estimasi parameter dari model ARIMA RUIS disajikan pada Tabel 8.

Tabel 8. Hasil estimasi parameter model ARIMA RUIS

\begin{tabular}{|c|c|c|c|c|}
\hline Model & Parameter & Coefficient & p-value & Signifikan \\
\hline $\begin{array}{c}\text { ARIMA } \\
(1,1,0)\end{array}$ & $\mathrm{AR}(1)$ & 0.152241 & 0.01889 & Ya \\
\hline \multirow{2}{*}{$\begin{array}{c}\text { ARIMA } \\
(1,1,1)\end{array}$} & $\mathrm{AR}(1)$ & -0.0032926 & 0.9901 & \multirow{2}{*}{ Tidak } \\
\hline & $\mathrm{MA}(1)$ & 0.1627043 & 0.5275 & \\
\hline \multirow{4}{*}{$\begin{array}{c}\text { ARIMA } \\
(1,1,3)\end{array}$} & $\mathrm{AR}(1)$ & 0.0260131 & 0.36411 & \multirow{4}{*}{ Tidak } \\
\hline & MA(1) & -0.113621 & 0.68596 & \\
\hline & $\mathrm{MA}(2)$ & -0.050418 & 0.51139 & \\
\hline & MA(3) & -0.134409 & 0.03897 & \\
\hline \multirow{3}{*}{$\begin{array}{c}\text { ARIMA } \\
(3,1,0)\end{array}$} & $\mathrm{AR}(1)$ & 0.152400 & 0.01864 & \multirow{3}{*}{ Tidak } \\
\hline & $\mathrm{AR}(2)$ & -0.048526 & 0.45959 & \\
\hline & $\mathrm{AR}(3)$ & -0.147198 & 0.02341 & \\
\hline \multirow{5}{*}{$\begin{array}{c}\text { ARIMA } \\
(3,1,3)\end{array}$} & $\mathrm{AR}(1)$ & 0.402169 & $2.2 \times 10^{-16}$ & \multirow{5}{*}{ Ya } \\
\hline & $\mathrm{AR}(2)$ & 0.422054 & $2.2 \times 10^{-16}$ & \\
\hline & $\mathrm{AR}(3)$ & -0.979148 & $2.2 \times 10^{-16}$ & \\
\hline & $\mathrm{MA}(1)$ & -0.414517 & $2.2 \times 10^{-16}$ & \\
\hline & $\mathrm{MA}(2)$ & -0.469010 & $2.2 \times 10^{-16}$ & \\
\hline
\end{tabular}

\begin{tabular}{|c|c|c|c|c|}
\hline & MA(3) & 0.941941 & $2.2 \times 10^{-16}$ & \\
\hline \multirow{3}{*}{$\begin{array}{c}\text { ARIMA } \\
(2,1,1)\end{array}$} & $\operatorname{AR}(1)$ & 0.684559 & 0.001669 & \multirow{3}{*}{ Ya } \\
\hline & $\operatorname{AR}(2)$ & -0.186383 & 0.004937 & \\
\hline & MA(1) & -0.525370 & 0.014103 & \\
\hline \multirow{4}{*}{$\begin{array}{c}\text { ARIMA } \\
(2,1,2)\end{array}$} & $\mathrm{AR}(1)$ & 1.401894 & $2.2 \times 10^{-16}$ & \multirow{4}{*}{ Ya } \\
\hline & $\mathrm{AR}(2)$ & -0.979374 & $2.2 \times 10^{-16}$ & \\
\hline & MA(1) & -1.413665 & $2.2 \times 10^{-16}$ & \\
\hline & MA(2) & 0.943050 & $2.2 \times 10^{-16}$ & \\
\hline $\begin{array}{c}\text { ARIMA } \\
(0,1,1)\end{array}$ & $\mathrm{MA}(1)$ & 0.159617 & 0.01183 & Ya \\
\hline \multirow{5}{*}{$\begin{array}{c}\text { ARIMA } \\
(3,1,2)\end{array}$} & $\mathrm{AR}(1)$ & 1.544541 & $2.2 \times 10^{-16}$ & \multirow{5}{*}{ Ya } \\
\hline & $\mathrm{AR}(2)$ & -1.167195 & $2.2 \times 10^{-16}$ & \\
\hline & $\mathrm{AR}(3)$ & 0.136647 & 0.04689 & \\
\hline & $\mathrm{MA}(1)$ & -1.448667 & $2.2 \times 10^{-16}$ & \\
\hline & $\mathrm{MA}(2)$ & 0.956763 & $2.2 \times 10^{-16}$ & \\
\hline
\end{tabular}

Untuk mengetahui model dapat dilihat dari nilai MAPE. Nilai MAPE untuk masing-masing model ARIMA 4 perusahaan disajikan pada Tabel 9.

Tabel 9. Nilai MAPE model ARIMA

\begin{tabular}{|c|c|c|}
\hline & Model & MAPE \\
\hline \multirow{4}{*}{ APEX } & ARIMA $(1,1,0)$ & 2.80301 \\
\hline & $\operatorname{ARIMA}(0,1,1)$ & 2.764987 \\
\hline & $\operatorname{ARIMA}(0,1,2)$ & 2.789863 \\
\hline & $\operatorname{ARIMA}(2,1,1)$ & 2.805497 \\
\hline \multirow{3}{*}{ ELSA } & $\operatorname{ARIMA}(1,1,1)$ & 2.058361 \\
\hline & $\operatorname{ARIMA}(3,1,1)$ & 1.98819 \\
\hline & ARIMA $(3,1,2)$ & 1.97583 \\
\hline \multirow{3}{*}{ MEDC } & $\operatorname{ARIMA}(1,1,1)$ & 3.193272 \\
\hline & $\operatorname{ARIMA}(2,1,2)$ & 3.193878 \\
\hline & $\operatorname{ARIMA}(4,1,4)$ & 2.957221 \\
\hline \multirow{6}{*}{ RUIS } & $\operatorname{ARIMA}(3,1,3)$ & 1.90784 \\
\hline & $\operatorname{ARIMA}(3,1,2)$ & 1.89665 \\
\hline & $\operatorname{ARIMA}(2,1,1)$ & 1.91154 \\
\hline & $\operatorname{ARIMA}(2,1,2)$ & 1.906668 \\
\hline & $\operatorname{ARIMA}(1,1,0)$ & 1.916048 \\
\hline & $\operatorname{ARIMA}(0,1,1)$ & 1.921408 \\
\hline
\end{tabular}

Berdasarkan Tabel 9, diperoleh model ARIMA terbaik untuk APEX, ELSA, MEDC, dan RUIS masing-masing, yaitu $\operatorname{ARIMA}(0,1,1)$, $\operatorname{ARIMA}(3,1,2), \operatorname{ARIMA}(4,1,4)$, dan $\operatorname{ARIMA}(3,1,2)$.

D. Uji Heteroskedastisitas

Pada uji heteroskedastisitas ini digunakan uji Lagrange Multiplier atau sering disebut uji ARCHLM dengan hipotesis $H_{0}$ tidak terdapat heteroskedastisitas pada model. Hasil uji ARCHLM pada model ARIMA terbaik disajikan pada Tabel 10.

Tabel 10. Hasil Uji ARCH-LM

\begin{tabular}{|c|c|c|c|}
\hline Data & Model & $p$-value & Kesimpulan \\
\hline APEX & $\begin{array}{c}\text { ARIMA } \\
(0,1,1)\end{array}$ & $1.614 \times 10^{-11}$ & Heteroskedastisitas \\
\hline ELSA & ARIMA & $1.718 \times 10^{-5}$ & Heteroskedastisitas \\
\hline
\end{tabular}

Nanda Septiana ${ }^{1}$, Primadina Hasanah ${ }^{2}$, Annisa Rahmita Soemarsono ${ }^{3 /}$ 


\begin{tabular}{|c|c|c|c|}
\hline & $(3,1,2)$ & & \\
\hline MEDC & $\begin{array}{c}\text { ARIMA } \\
(4,1,4)\end{array}$ & 0.9466 & Homoskedastisitas \\
\hline RUIS & $\begin{array}{c}\text { ARIMA } \\
(3,1,2)\end{array}$ & 0.002153 & Heteroskedastisitas \\
\hline
\end{tabular}

Berdasaran Tabel 10, diperoleh kesimpulan bahwa terdapat gejala heteroskedastisitas pada model ARIMA terbaik untuk data perusahaan APEX, ELSA, dan RUIS. Sedangkan untuk data perusahaan MEDC tidak terdapat efek heteroskedastisitas atau dapat dikatakan terdapat gejala homoskedastisitas pada model ARIMA yang artinya pada MEDC akan digunakan model ARIMA untuk forecast. Selanjutnya akan dilakukan pembentukan model GARCH pada model ARIMA APEX, ELSA, dan RUIS karena terdapat efek ARCH atau dengan kata lain model mengandung unsur heteroskedastisitas.

\section{E. Estimasi Model ARIMA-GARCH}

Pada estimasi model $\operatorname{GARCH}(p, d, q)$ dilakukan dengan metode maximum likelihood dengan orde $p$ dan $q$ dapat dilihat pada correlogram ACF dan PACF dari residual kuadrat model ARIMA terbaik. Orde $p$ merupakan orde AR yang dapat dilihat pada correlogram PACF, orde $q$ merupakan orde MA dapat dilihat pada correlogram ACF. Berikut correlogram ACF dan PACF dari residual kuadrat model ARIMA terbaik:
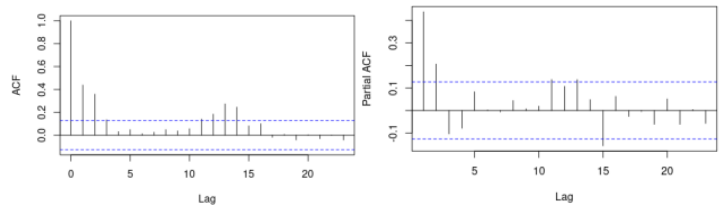

(a)
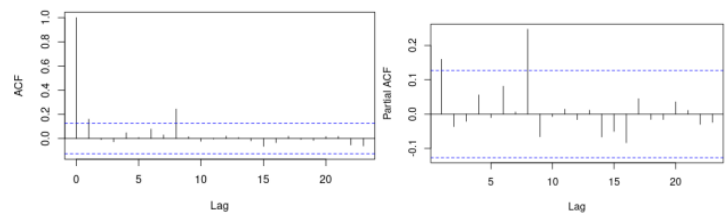

(b)
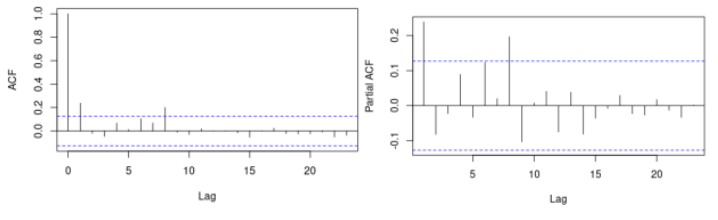

(c)

Gambar 3. Correlogram ACF dan PACF residual kuadrat model ARIMA (a) APEX, (b) ELSA, (c) MEDC, (d) RUIS
Pada ACF residual kuadrat APEX, terpotong pada lag 0,1 , dan 2 . Untuk PACF residual kuadrat APEX terpotong pada lag 1 dan 2. Pada ACF residual kuadrat ELSA, terpotong pada lag 0 dan 1. Untuk PACF residual kuadrat ELSA terpotong pada lag 1. Pada ACF residual kuadrat RUIS, terpotong pada lag 0 dan 1 . Untuk PACF residual kuadrat RUIS terpotong pada lag 1. Setelah didapatkan orde ARIMA-GARCH dilakukan estimasi parameter untuk uji signifikan model pendugaan dan model overfitting dengan hipotesis $H_{0}$ model tidak signifikan. Hasil estimasi parameter dari model ARIMA-GARCH APEX disajikan pada Tabel 11.

Tabel 11. Hasil estimasi model ARIMAGARCH APEX

\begin{tabular}{|c|c|c|c|c|}
\hline Model & Parameter & Coefficient & $p$-value & Signifikan \\
\hline \multirow{3}{*}{ ARIMA(0,1,1) } & $\mu$ & 24.32242 & $2 \times 10^{-16}$ & \\
\cline { 2 - 4 } GARCH(1,0) & MA(1) & 0.69605 & $2 \times 10^{-16}$ & \multirow{2}{*}{ Ya } \\
\cline { 2 - 4 } & $\omega$ & 0.99651 & $1.39 \times 10^{-10}$ & \\
\cline { 2 - 4 } & $\alpha_{1}$ & 0.82816 & $1.80 \times 10^{-13}$ & \\
\hline & $\mu$ & 24.27698 & $2 \times 10^{-16}$ & \multirow{2}{*}{ Ya } \\
\cline { 2 - 4 } ARIMA(0,1,1) & $\mathrm{MA}(1)$ & 073146 & $2 \times 10^{-16}$ & \\
\cline { 2 - 4 } & $\omega$ & 0.22404 & $2 \times 10^{-16}$ & \\
\cline { 2 - 4 } & $\alpha_{1}$ & 0.49002 & $1.60 \times 6$ & \\
\cline { 2 - 4 } & $\beta_{1}$ & 0.48433 & $1.39 \times 10^{-10}$ & \\
\end{tabular}

Berdasarkan Tabel 11, didapatkan model yang signifikan, yaitu ARIMA $(0,1,1) \mathrm{GARCH}(1,0)$ dan ARIMA $(0,1,1) \operatorname{GARCH}(1,1)$. Hasil estimasi parameter dari model ARIMA-GARCH ELSA disajikan pada Tabel 12.

Tabel 12. Hasil estimasi model ARIMAGARCH ELSA

\begin{tabular}{|c|c|c|c|c|}
\hline Model & Parameter & Coefficient & $p$-value & Signifikan \\
\hline \multirow{8}{*}{$\begin{array}{c}\operatorname{ARIMA}(3,1,2) \\
\operatorname{GARCH}(1,0)\end{array}$} & $\mu$ & -0.6369 & 0.371882 & \multirow{8}{*}{ Tidak } \\
\hline & $\overline{\mathrm{AR}(1)}$ & 0.2655 & 0.124965 & \\
\hline & $\mathrm{AR}(2)$ & 0.2855 & 0.082169 & \\
\hline & AR(3) & 0.4605 & 0.000461 & \\
\hline & $\mathrm{MA}(1)$ & 0.8335 & $2.65 \times 10^{-9}$ & \\
\hline & MA(2) & 0.5805 & $2.07 \times 10^{-6}$ & \\
\hline & $\omega$ & 0.9966 & $2.91 \times 10^{-9}$ & \\
\hline & $\alpha_{1}$ & 0.9860 & $1.94 \times 10^{-7}$ & \\
\hline \multirow{9}{*}{$\begin{array}{c}\operatorname{ARIMA}(3,1,2) \\
\operatorname{GARCH}(1,1)\end{array}$} & $\mu$ & 0.05755 & 0.957140 & \multirow{9}{*}{ Ya } \\
\hline & $\mathrm{AR}(1)$ & 0.01714 & 0.966657 & \\
\hline & $\mathrm{AR}(2)$ & 0.51161 & 0.183560 & \\
\hline & $\mathrm{AR}(3)$ & 0.47402 & 0.001823 & \\
\hline & $\mathrm{MA}(1)$ & 1.000000 & 0.003236 & \\
\hline & MA(2) & 0.52277 & 0.003327 & \\
\hline & $\omega$ & 0.46162 & $2.1 \times 10^{-11}$ & \\
\hline & $\alpha_{1}$ & 0.71352 & $2.81 \times 10^{-5}$ & \\
\hline & $\beta_{1}$ & 0.30903 & 0.000619 & \\
\hline \multirow{4}{*}{$\begin{array}{c}\operatorname{ARIMA}(0,1,1) \\
\operatorname{GARCH}(1,0)\end{array}$} & $\mu$ & 59.5781 & $2 \times 10^{-16}$ & \multirow{4}{*}{ Ya } \\
\hline & MA(1) & 0.7366 & $2 \times 10^{-16}$ & \\
\hline & $\omega$ & 3.1623 & $4.86 \times 10^{-9}$ & \\
\hline & $\alpha_{1}$ & 0.8675 & $7.77 \times 10^{-15}$ & \\
\hline \multirow{5}{*}{$\begin{array}{c}\operatorname{ARIMA}(0,1,1) \\
\operatorname{GARCH}(1,1)\end{array}$} & $\mu$ & 59.03431 & $2 \times 10^{-16}$ & \multirow{5}{*}{ Ya } \\
\hline & MA(1) & 0.79956 & $2 \times 10^{-16}$ & \\
\hline & $\omega$ & 0.38644 & 0.063 & \\
\hline & $\alpha_{1}$ & 0.51335 & $2.83 \times 10^{-6}$ & \\
\hline & $\beta_{1}$ & 0.50757 & $2.02 \times 10^{-10}$ & \\
\hline
\end{tabular}


Berdasarkan Tabel 12, didapatkan model yang signifikan, yaitu $\operatorname{ARIMA}(0,1,1) \operatorname{GARCH}(1,0)$, $\operatorname{ARIMA}(0,1,1) \mathrm{GARCH}(1,1)$, dan ARIMA(1,1,0)GARCH(1,0). Hasil estimasi parameter dari model ARIMA-GARCH RUIS disajikan pada Tabel 13.

Tabel 13. Hasil estimasi model ARIMAGARCH RUIS

\begin{tabular}{|c|c|c|c|c|}
\hline Model & Parameter & Coefficient & $p$-value & Signifikan \\
\hline \multirow{8}{*}{$\begin{array}{c}\operatorname{ARIMA}(3,1,2) \\
\operatorname{GARCH}(1,0)\end{array}$} & $\mu$ & 0.4150 & $2 \times 10^{-16}$ & \multirow{8}{*}{ Tidak } \\
\hline & $\mathrm{AR}(1)$ & 0.2990 & $2 \times 10^{-16}$ & \\
\hline & $\mathrm{AR}(2)$ & 0.9518 & $2 \times 10^{-16}$ & \\
\hline & $\mathrm{AR}(3)$ & -0.2632 & $2 \times 10^{-16}$ & \\
\hline & MA(1) & 0.6626 & $2 \times 10^{-16}$ & \\
\hline & $\mathrm{MA}(2)$ & -0.4235 & $2 \times 10^{-16}$ & \\
\hline & $\omega$ & 0.5561 & $\begin{array}{l}9.11 \\
\times 10^{-12} \\
\end{array}$ & \\
\hline & $\alpha_{1}$ & 0.4372 & 0.1046 & \\
\hline \multirow{4}{*}{$\begin{array}{c}\operatorname{ARIMA}(0,1,1) \\
\operatorname{GARCH}(1,0)\end{array}$} & $\mu$ & 30.60226 & $2 \times 10^{-16}$ & \multirow{4}{*}{ Ya } \\
\hline & MA(1) & 0.71526 & $2 \times 10^{-16}$ & \\
\hline & $\omega$ & 0.88521 & $1.44 \times 10^{-5}$ & \\
\hline & $\alpha_{1}$ & 0.96839 & $\begin{array}{l}8.88 \\
\times 10^{-16} \\
\end{array}$ & \\
\hline \multirow{5}{*}{$\begin{array}{c}\operatorname{ARIMA}(0,1,1) \\
\operatorname{GARCH}(1,1)\end{array}$} & $\mu$ & 36.47111 & $2 \times 10^{-16}$ & \multirow{5}{*}{ Ya } \\
\hline & MA(1) & 0.85021 & $2 \times 10^{-16}$ & \\
\hline & $\omega$ & 0.17574 & 0.080717 & \\
\hline & $\alpha_{1}$ & 0.31886 & 0.000129 & \\
\hline & $\beta_{1}$ & 0.66445 & $2 \times 10^{-16}$ & \\
\hline
\end{tabular}

Berdasarkan Tabel 13, didapatkan model yang signifikan, yaitu $\operatorname{ARIMA}(0,1,1) \operatorname{GARCH}(1,0)$ dan ARIMA(0,1,1)GARCH(1,1). Untuk mengetahui model terbaik dapat dilihat dari nilai AIC. Nilai AIC untuk masing-masing model ARIMAGARCH 4 perusahaan disajikan pada Tabel 14.

Tabel 14. Nilai AIC model ARIMA-GARCH

\begin{tabular}{|c|c|c|}
\hline & Model & AIC \\
\hline \multirow{3}{*}{ APEX } & $\begin{array}{c}\text { ARIMA(1,1,0) } \\
\text { GARCH(1,0) }\end{array}$ & 4.612655 \\
\cline { 2 - 3 } & $\begin{array}{c}\text { ARIMA(0,1,1) } \\
\text { GARCH(1,1) }\end{array}$ & 2.543815 \\
\hline \multirow{3}{*}{ ELSA } & $\begin{array}{c}\text { ARIMA(1,1,0) } \\
\text { GARCH(1,0) }\end{array}$ & $\begin{array}{c}\text { ARIMA(0,1,1) } \\
\text { GARCH(1,1) }\end{array}$ \\
\hline \multirow{2}{*}{ RUIS } & $\begin{array}{c}\text { ARIMA(1,1,0) } \\
\text { GARCH(1,0) }\end{array}$ & 5.65927 \\
\cline { 2 - 3 } & $\begin{array}{c}\text { ARIMA(0,1,1) } \\
\text { GARCH(1,1) }\end{array}$ & 4.873360 \\
\hline
\end{tabular}

Berdasarkan Tabel 14, diperoleh model ARIMA-GARCH terbaik untuk APEX, ELSA, dan RUIS, yaitu ARIMA $(0,1,1) \operatorname{GARCH}(1,1)$.

\section{F. Uji Diagnostik}

Uji diagnostik dilakukan untuk menganalisis uji asumsi residual dari model yang didapatkan. Pada uji diagnostik ini, model akan di uji asumsi residualnya yaitu uji autokorelasi, uji normalitas, dan uji homoskedastisitas. Pada uji diagnostik, digunakan Jarque-Bera Test untuk uji normalitas dengan hipotesis $H_{0}$ residual data berdistribusi normal, Ljung-Box Test untuk uji autokorelasi dengan hipotesis $H_{0}$ tidak terdapat autokerelasi pada residual data, dan ARCH-LM Test untuk uji Heteroskedastisitas dengan hipotesis $H_{0}$ tidak terdapat gejala heteroskedastisitas pada residual data. Uji diagnostik model ARIMA-GARCH untuk perusahaan APEX, ELSA, dan RUIS serta model ARIMA untuk perusahaan MEDC disajikan pada Tabel 15.

Tabel 15. Uji diagnostik model ARIMA dan ARIMA-GARCH

\begin{tabular}{|c|c|c|c|c|}
\hline \multirow{2}{*}{ Data } & Model & $\begin{array}{c}\text { Uji } \\
\text { Normalita } \\
\text { s }\end{array}$ & $\begin{array}{c}\text { Uji } \\
\text { Autokorel } \\
\text { asi }\end{array}$ & $\begin{array}{c}\text { Uji } \\
\text { Heterosked } \\
\text { astisitas }\end{array}$ \\
\hline \multirow{2}{*}{ ELSA } & $\begin{array}{c}\text { ARIMA } \\
(0,1,1) \\
\text { GARCH } \\
(1,1)\end{array}$ & 0.3025 & 0 & 0.3735 \\
& $\begin{array}{c}\text { ARIMA } \\
(0,1,1) \\
\text { GARCH } \\
(1,1)\end{array}$ & $\begin{array}{l}3.898 \\
\times 10^{-3}\end{array}$ & $\begin{array}{l}8.182 \\
\times 10^{12}\end{array}$ & $\begin{array}{l}3.583 \\
\times 10^{-8}\end{array}$ \\
\hline MEDC & $\begin{array}{c}\text { ARIMA } \\
(4,1,4)\end{array}$ & $\begin{array}{l}2.2 \\
\times 10^{-16}\end{array}$ & 0.9961 & 0.9466 \\
\hline RUIS & $\begin{array}{c}\text { ARIMA } \\
(0,1,1) \\
\text { GARCH } \\
(1,0)\end{array}$ & 0.0029 & 0 & 0.00032 \\
\hline
\end{tabular}

Berdasarkan Tabel 15, uji normalitas pada model 4 perusahaan dapat disimpulkan bahwa hanya model ARIMA-GARCH APEX yang memiliki residual data berdistribusi normal. Untuk uji autokorelasi pada model 4 perusahaan disimpulkan bahwa hanya pada model ARIMA MEDC yang tidak terdapat autokolerasi pada data. Untuk uji heteroskedastisitas pada model 4 perusahaan dapat disimpulkan bahwa hanya model ARIMA MEDC dan ARIMA-GARCH APEX tidak terdapat heteroskedastisitas pada residual data.

\section{G. Peramalan}

Setelah didapatkan model ARIMA dan ARIMA-GARCH pada 4 perusahaan, selanjutnya dilakukan forecasting atau peramalan dengan model yang telah didapatkan yang disajikan pada Tabel 16.

Tabel 16. Model ARIMA dan ARIMA-GARCH

\begin{tabular}{|c|c|}
\hline Perusahaan & Model \\
\hline APEX & ARIMA $(0,1,1)$ GARCH $(1,1)$ \\
\hline ELSA & ARIMA $(0,1,1) \operatorname{GARCH}(1,1)$ \\
\hline
\end{tabular}




\begin{tabular}{|c|c|}
\hline MEDC & ARIMA $(4,1,4)$ \\
\hline RUIS & ARIMA $(0,1,1)$ GARCH $(1,1)$ \\
\hline
\end{tabular}

Berdasarkan Tabel 16, didapatkan persamaan matematis untuk model ARIMA dan ARIMAGARCH sebagai berikut:

1. Model ARIMA $(0,1,1)$ GARCH(1,1) APEX

Pada model ARIMA-GARCH APEX didapatkan persamaan matematis sebagai berikut:

$Y_{t}=24.27968+Y_{t-1}+0.73146 e_{t-1}+e_{t}$ dan

$$
\begin{aligned}
\sigma_{t}^{2}= & 0.99651+0.49002 e_{t-1}^{2}+0.48433 \sigma_{t-1}^{2} \\
& +e_{t}
\end{aligned}
$$

2. Model ARIMA $(0,1,1)$ GARCH $(1,1)$ ELSA

Pada model ARIMA-GARCH ELSA didapatkan persamaan matematis sebagai berikut:

$$
\begin{aligned}
& Y_{t}=59.03431+Y_{t-1}+0.79956 e_{t-1}+e_{t} \\
& \text { dan } \\
& \begin{aligned}
\sigma_{t}^{2}= & 3.8644+0.51335 e_{t-1}^{2}+0.50757 \sigma_{t-1}^{2} \\
& +e_{t}
\end{aligned}
\end{aligned}
$$

3. Model ARIMA $(4,1,4)$ MEDC

Pada model ARIMA-GARCH ELSA didapatkan persamaan matematis sebagai berikut:

$$
\begin{aligned}
Y_{t}= & Y_{t-1}-0.639064 Y_{t-1}+0.639064 Y_{t-2} \\
& +0.188087 Y_{t-2}-0.188087 Y_{t-3} \\
& -0.641934 Y_{t-3}+0.641934 Y_{t-4} \\
& -0.936179 Y_{t-4}+0.936179 Y_{t-5} \\
& +0.711261 e_{t-1}-0.221940 e_{t-2} \\
& +0.712097 e_{t-3}+0.999032 e_{t-4} \\
& +e_{t}
\end{aligned}
$$

4. Model ARIMA $(0,1,1)$ GARCH(1,0) RUIS

Pada model ARIMA-GARCH APEX didapatkan persamaan matematis sebagai berikut:

$$
\begin{aligned}
& Y_{t}=36.47111+Y_{t-1}+0.850216 e_{t-1} \\
& +e_{t} \\
& \text { dan } \\
& \begin{array}{l}
\sigma_{t}^{2}= \\
\quad \\
\quad \\
\quad+e_{t}
\end{array}
\end{aligned}
$$

Setah didapatkan model untuk 4 perusahaan, maka dilakuakn forecasting, yaitu meramalkan 10 data harga saham penutupan untuk masing-maisng 4 perusahaan untuk mengukur nilai akurasi dengan membandingkan data hasil peramalan dan data riil, di mana akan diramalkan harga saham penutupan dari tanggal 1 Maret 2021. Hasil peramalan 4 perusahan dapat dilihat pada plot sebagai berikut:

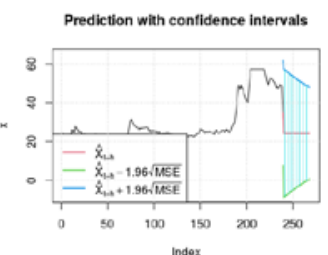

(a)

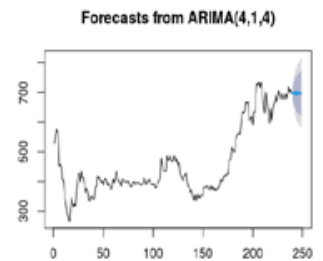

(c)

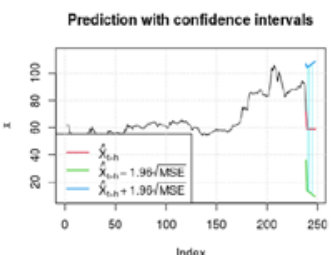

(b)

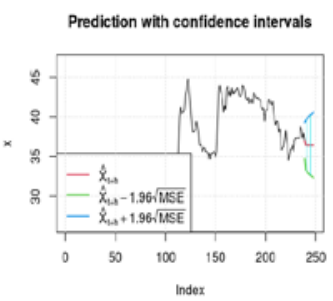

(d)
Gambar 3. Plot hasil peramalan (a) APEX, (b) ELSA, (c) MEDC, (d) RUIS

Berdasarkan Gambar 3, hasil peramalan masih dalam bentuk transformasi. Oleh karena itu diperlukan pengembalian data transformasi ke data asli dengan menggunakan Persamaan (3). Hasil peramalan setelah pengembalian data transformasi ke data asli disajikan pada Tabel 17.

Tabel 17. Hasil peramalan ARIMA dan ARIMA-GARCH

\begin{tabular}{|c|c|c|c|c|}
\hline \multirow{2}{*}{ No } & \multicolumn{4}{|c|}{ Forcasting } \\
\cline { 2 - 5 } & APEX & ELSA & MEDC & RUIS \\
\hline 1 & 285.0054 & 285.4715 & 695.5060 & 245.5738 \\
\hline 2 & 149.9544 & 218.0348 & 701.0539 & 239.6236 \\
\hline 3 & 149.9544 & 218.0348 & 691.6119 & 239.6236 \\
\hline 4 & 149.9544 & 218.0348 & 703.3553 & 239.6236 \\
\hline 5 & 149.9544 & 218.0348 & 690.0395 & 239.6236 \\
\hline 6 & 149.9544 & 218.0348 & 701.6252 & 239.6236 \\
\hline 7 & 149.9544 & 218.0348 & 693.0176 & 239.6236 \\
\hline 8 & 149.9544 & 218.0348 & 698.2515 & 239.6236 \\
\hline 9 & 149.9544 & 218.0348 & 698.3164 & 239.6236 \\
\hline 10 & 149.9544 & 218.0348 & 693.9386 & 239.6236 \\
\hline
\end{tabular}

Berdasarkan Tabel 17, akan dibandingkan dengan data out sample dari harga saham penutupan masing-masing 4 perusahaan dari tangal 1 Maret 2021. Perbandingan ini bertujuan untuk mengukur kesalahan dalam model ARIMA dan ARIMA-GARCH berdasarkan nilai Mean Absolute Precentage Error (MAPE) dengan rumus sebagai berikut:

$$
M A P E=\frac{1}{n} \sum_{t=1}^{n}\left|\frac{Y_{t}-\widehat{Y}_{t}}{Y_{t}}\right| \times 100 \%
$$

Berdasarkan rumus MAPE didapatkan hasil akurasi peramalan untuk masing-masing 4 perusahaan disajikan pada Tabel 18. 
Tabel 18. Hasil akurasi peramalan

\begin{tabular}{|c|c|c|}
\hline No & Perusahaan & MAPE \\
\hline 1 & APEX & $67.32667 \%$ \\
\hline 2 & ELSA & $42.49374 \%$ \\
\hline 3 & MEDC & $5.269889 \%$ \\
\hline 4 & RUIS & $4.113383 \%$ \\
\hline
\end{tabular}

Berdasarkan Tabel 18, untuk model ARIMAGARCH APEX dan ELSA didapatkan nilai MAPE di atas $10 \%$. Maka untuk model ARIMA-GARCH belum dikatakan baik digunakan untuk peramalan harga saham perusahaan APEX dan ELSA. Untuk model ARIMA pada MEDC dan ARIMA-GARCH RUIS didapatkan nilai MAPE dibawah 10\%. Maka untuk model dapat dikatakan baik digunakan untuk peramalan harga saham perusahaan MEDC dan RUIS.

\section{KESIMPULAN DAN SARAN}

A. Kesimpulan

Berdasarkan hasil dan pembahasan diperoleh kesimpulan sebagai berikut:

1. Model ARIMA dan ARIMA-GARCH untuk peramalan harga penutupan saham harian sebagai berikut:

- APEX didapatkan model mean atau ARIMA dengan orde $\operatorname{AR}(p)$ adalah 0 dan $\operatorname{MA}(q)$ adalah 1 dengan satu kali differencing sedangkan model varian atau GARCH didapatkan orde $\operatorname{ARCH}(p)$ adalah 1 dan orde GARCHq) adalah 1.

- ELSA didapatkan model mean atau ARIMA dengan orde $\operatorname{AR}(p)$ adalah 0 dan $\operatorname{MA}(q)$ adalah 1 dengan satu kali differencing sedangkan model varian atau GARCH didapatkan orde $\operatorname{ARCH}(p)$ adalah 1 dan orde GARCH $q$ ) adalah 1.

- MEDC didapatkan model mean atau ARIMA dengan orde $\operatorname{AR}(p)$ adalah 4 dan $\operatorname{MA}(q)$ adalah 4 .

- RUIS didapatkan model mean atau ARIMA dengan orde $\operatorname{AR}(p)$ adalah 0 dan $\operatorname{MA}(q)$ adalah 1 dengan satu kali differencing sedangkan model varian atau GARCH didapatkan orde $\operatorname{ARCH}(p)$ adalah 1 dan orde GARCH $q$ ) adalah 1.

2. Hasil forecasting atau peramalan untuk 10 hari kedepan yang dimulai pada tanggal 01 Maret 2021. Dari hasil peramalan didapatkan nilai akurasi yang diperoleh dengan membandingkan data hasil peramalan dan data out sample berdasarkan nilai MAPE yaitu untuk APEX diperoleh nilai akurasi 67.32667\%, untuk ELSA diperoleh nilai akurasi 41.82999\%, untuk MEDC diperoleh nilai akurasi 5.269889\%, dan untuk RUIS diperoleh nilai akurasi 4.113383\%. Dari nilai MAPE yang diperoleh, hasil akurasi untuk model peramalan ARIMA-GARCH untuk APEX dan ELSA masih di atas 10\% yang di artikan model belum baik digunakan untuk peramalan. Sedangkan untuk nilai MAPE yang diperoleh untuk model peramalan ARIMA dan ARIMA-GARCH untuk MEDC dan RUIS sudah di bawah 10\% yang di artiakn model sudah cukup baik digunakan untuk peramalan.

\section{B. Saran}

Saran yang dapat diberikan untuk penelitian selanjutnya yaitu membandingkan dengan metode lain seperti perbandingan dengan Fuzzy Time Series Markov Chain. Metode ARIMA memiliki keterbatasan yaitu hanya meramalkan untuk jangka pendek. Maka dari itu, untuk penelitian selanjutnya menggunakan metode peramalan lain yang dapat meramalkan untuk jangka waktu yang panjang seperti Generalized Regression Neural Network. Penelitian selanjutnya disarankan melanjutkan dengan menggunakan metode dari pengembangan GARCH yaitu seperti EGARCH, IGARCH, GARCH-M, dan TGARCH untuk mengatasi uji diagnostik yang belum terpenuhi dan menghasilkan nilai akurasi MAPE dibawah 10\%.

\section{DAFTAR PUSTAKA}

Angraeny, Nella. 2019. Penerapan Metode ARCH GARCH untuk Analisis Peramalan Nilai Ekspor Indonesia. Skripsi. FMIPA, Matematika, Universitas Negeri Semarang, Semarang.

Ati, Enggar Niken Laras. 2015. Analisis Volatilitas Forcasting Sembilan Bahan Pokok menggunakan Metode GARCH dengan Program R. Skripsi. FMIPA, Matematika, Universitas Negeri Semarang, Semarang.

Darmayati, Novi dkk. 2020. Dampak Vovid-19 Terhadap Perubahan Harga dan Return Saham. Jurnal Ekonomi dan Keuangan, Vol. 4 No. 4, Hal. 462-480

Faustina, Riza Silvia dkk. 2017. Model Hybrid ARIMA-GARCH untuk Estimasi Volatilitas Harga Emas Menggunakan Software R. UNNES Journal of Mathematics. Vol. 6 No. 1, Hal. 11-24 
Farizah, Icak (2017), “Penerapan Model GARCH dalam Mengukur Risioko Berinvestasi”. Skripsi. Fakultas Sains dan Teknologi, Matematika, Universitas Islam Negeri Alaudin, Makassar.

Hikmah, Nur Falilah Nurul Hikmah. 2018. Perbandingan Metode Arima-Garch Dan Fuzzy Time Series Markov Chain Dalam Peramalan Data Harga Minyak Mentah Dunia (Studi Kasus: Data Harga Minyak Mentah Dunia Tahun 2001-2017). Skripsi. FMIPA, Statistika, Universitas Islam Indonesia, Yogyakarta.

Raneo, Agung Putra dan Fida Muthia 2018. Penerapan Model GARCH dalam Peramalan Volatilitas di Bursa Efek Indonesia. Jurnal Manajemen dan Bisnis Sriwijaya, Vol. 15 No. 3, Hal 194-202

Wicaksono, Agung dan Rahandika Ivan Adyaksana. 2020. Analisis Reaksi Investor Sebagai Dampak Covid-19 pada Sektor Perbankan di Indonesia. Jurnal Ilmiah Akuntansi Fakultas Ekonomi. Vol. 6 No. 2, Hal. 129-138

Widyastuti, Nur Laila dan Hanan Nugroho. 2020. Dampak Covid-19 terhadap Industri Minyak dan Gas Bumi: Rekomendasi Kebijakan untuk Indonesia. The Indonesian Journal of Development Planning. Vol. 4 No. 2, Hal. 166-176

Yolanda, Natasya Bella dkk. 2017. Penerapan Model ARIMA-GARCH untuk Memprediksi Harga Saham Bank BRI. Jurnal MIPA UNSRAT. Vol. 6 No. 2, Hal. 92-96 